\title{
Formulasi Gel Ekstrak Daun Kelor (Moringa oleifera Lamk) Sebagai Sediaan Antiinflamasi
}

\section{Formulation of Moringa oleifera Leaf Extract As Anti-Inflammatory Gel Dosage Form}

\author{
Nining Sugihartini", Syauqul Jannah, Tedjo Yuwono \\ Fakultas Farmasi, Universitas Ahmad Dahlan, Jakarta, Indonesia
}

\begin{abstract}
ABSTRAK
Pengembangan bentuk sediaan gel antiinflamasi dari ekstrak daun kelor telah dilakukan. Tujuan dari penelitian ini adalah mengetahui sifat fisik, indeks iritasi dan daya antiinflamasi gel dengan variasi konsentrasi ekstrak daun kelor. Ekstrak diperoleh dengan metode maserasi menggunakan pelarut etanol 70\%. Ekstrak diformulasikan dalam bentuk gel pada konsentrasi 3\%, 6\%, 9\% dengan menggunakan Karbopol 940 sebagai gelling agent. Gel dievaluasi sifat fisiknya (viskositas, pH, daya sebar, daya lekat), indeks iritasi dengan hewan uji kelinci dan daya antiinflamasi dengan hewan uji mencit berdasarkan parameter tebal epidermis. Hasil uji menunjukkan bahwa peningkatan konsentrasi ekstrak menyebabkan perubahan viskositas, $\mathrm{pH}$, daya lekat, tebal epidermis serta daya sebar. Berdasarkan hasil uji dapat disimpulkan bahwa konsentrasi optimum ekstrak daun kelor dalam gel sebagai antiinflamasi adalah $3 \%$.
\end{abstract}

Kata kunci: gel; ekstrak daun kelor; antiinflamasi; sifat fisik; tebal epidermis

\begin{abstract}
The development of anti-inflammatory gel of Moringa oleifera leaf extract has been performed. This study aimed to determine the physical properties, irritation index and anti-inflammatory activity of gel with various concentration of Moringa oleifera leaf extract. The extract was obtained by maceration method using ethanol $70 \%$. The extracts were formulated in a gel with a concentration of 3\%, 6\%, 9\% by using Carbopol 940 as gelling agent. The gel was evaluated for its physical properties (viscosity, $\mathrm{pH}$, spreadability, adhesivity), irritation index with rabbit test animals and anti-inflammatory activity with mice test animals based on epidermal thickness parameters. The test results showed that the increasing of extract concentration changed the viscosity, $\mathrm{pH}$, adhesivity, epidermal thickness and spreadability of the gel. Based on the results of this study it can be concluded that the optimum concentration of Moringa oleifera leaf extract in gel as anti-inflammatory was 3\%.
\end{abstract}

Key words: gel; Moringa oleifera leaf extract; anti-inflammatory; physical properties; epidermal thickness

*corresponding author

Email: nining.sugihartini@pharm.uad.ac.id

\section{PENDAHULUAN}

Inflamasi merupakan respon tubuh ketika mengalami cedera, adanya infeksi, antigen atau kerusakan sel sehingga merupakan pertanda adanya hal yang membahayakan tubuh atau terjadinya penyakit (Lima dkk., 2011; Souto dkk., 2011). Respon inflamasi ditandai oleh kondisi berupa rubor (kemerahan), kalor (panas), dolor (nyeri), tumor (pembengkakan) dan gangguan fungsi (Corwin, 2008). Inflamasi dapat bersifat lokal dan sistemik, dapat juga terjadi secara akut atau kronis yang menimbulkan kelainan patologis.
Salah satu tempat yang dapat mengalami inflamasi adalah kulit sehingga pengembangan bentuk sediaan antiinflamasi khususnya yang bersifat lokal telah dilakukan. Keuntungan dari pemberian sediaan obat antiinflamasi secara topikal adalah dapat langsung dioleskan pada tempat yang mengalami inflamasi sehingga langsung dapat memberikan efek, pelepasan obatnya secara perlahan-lahan sehingga durasi efeknya bisa lebih lama dan menurunkan frekuensi penggunaan sehingga tingkat kepatuhan pasien bisa meningkat (Zhang dkk., 2019). Beberapa penelitian sebelumnya telah memformulasikan sediaan antiinflamasi dalam bentuk sediaan gel, krim dan salep (Santos dkk., 2018; Srirod dan Tewtrakul, 2019; Dev dkk., 2019; Carvalho dkk., 2019; Yakota dan Kyotani, 2018). 
Tabel 1. Formula gel ekstrak daun kelor dengan variasi konsentrasi ekstrak

\begin{tabular}{llll}
\hline Bahan & FI & FII & FIII \\
\hline Ekstrak Daun Kelor & 0,6 & 1,2 & 1,8 \\
Karbopol 940 & $1 \mathrm{~g}$ & $1 \mathrm{~g}$ & $1 \mathrm{~g}$ \\
TEA & $0,05 \mathrm{~g}$ & $0,05 \mathrm{~g}$ & $0,05 \mathrm{~g}$ \\
Gliserin & $2 \mathrm{~g}$ & $2 \mathrm{~g}$ & $2 \mathrm{~g}$ \\
Propilenglikol & $1 \mathrm{~g}$ & $1 \mathrm{~g}$ & $1 \mathrm{~g}$ \\
Metil Paraben & $0,03 \mathrm{~g}$ & $0,03 \mathrm{~g}$ & $0,03 \mathrm{~g}$ \\
Aquadest sampai & $20 \mathrm{~g}$ & $20 \mathrm{~g}$ & $20 \mathrm{~g}$ \\
\hline
\end{tabular}

Salah satu tanaman yang telah dibuktikan memiliki aktivitas sebagai antiinflamasi adalah kelor (Moringa oleifera) (Mahajan et al, 2007ª ; Mahajan et al, 2007b). Beberapa hasil skrining fitokimia tanaman kelor ditemukan senyawa tanin, flavonoid, saponin. Senyawa yang diduga mempunyai efek sebagai antiinflamasi adalah flavonoid. Hasil uji in vitro ekstrak daun kelor yang mengandung flavonoid ternyata memiliki aktifitas dapat menghambat produksi PgE2 (Prostaglandin E2) dan aktivitas COX-2 (Siklooksigenase 2) yang diinduksi oleh liposakarida (Lutfiana, 2013).

Potensi ekstrak daun kelor sebagai antiinflamasi mendorong penelitian lanjutan untuk memformulasikannya dalam bentuk sediaan gel. Penelitian lainnya juga telah menggunakan gel sebagai bentuk sediaan dalam pengobatan antiinflamasi (Gupta \& Gand, 2006). Keuntungan sediaan gel adalah efek pendinginan pada kulit saat digunakan, penampilan sediaan yang jernih dan elegan, pada pemakaian di kulit setelah kering meninggalkan film tembus pandang, elastis, mudah dicuci dengan air, pelepasan obatnya baik, kemampuan penyebarannya pada kulit baik. Dalam penelitian ini akan dikaji pengaruh kosentrasi ekstrak terhadap sifat fisik, iritasi dan daya antiinflamasi agar dapat diketahui kosentrasi ekstrak yg memberikan sifat fisik dan daya antiinflamasi yang baik dan tidak mengiritasi.

\section{METODE}

\section{Bahan dan Alat}

Bahan utama yang digunakan adalah daun kelor yang sudah dikeringkan dengan menggunakan sinar matahari secara tidak langsung yaitu ditutupi kain hitam, daun basahnya diambil dari dari Kabupaten Pati, Jawa Tengah. Bahan formulasi gel dengan derajat farmasetis yang digunakan meliputi; gliserin (Brataco, Indonesia), propilenglikol (Brataco, Indonesia), trietanolamin/TEA (Brataco, Indonesia), metil paraben (Brataco, Indonesia),
Carbopol 940 No 15. (Brataco, Indonesia). Bahan untuk uji anti inflamasi adalah croton oil, veed, formalin, bahan pengecatan hematoxylin \& eosin, mencit galur BALB/c, umur 2-3 bulan dengan berat 20 gram dan kelinci albino galur New Zaeland dengan berat 2,5 kg.

Alat yang digunakan dalam penelitian ini meliputi seperangkat alat gelas (Pirex, Indonesia), pengaduk, waterbath (Nurius, China), cawan porselen, mortir, stamper, timbangan analitik (Ohaus, Jepang), seperangkat alat uji daya sebar, daya lekat, $\mathrm{pH}$ meter (Lutron PH-208, China), Mikroskop cahaya (Olympus, Jepang), dan Viscometer (Brookfield DV2T, Jerman).

\section{Ekstraksi Simplisia Daun kelor}

Ekstrak etanol diperoleh dengan menggunakan metode maserasi dengan pelarut etanol $70 \%$ dengan perbandingan 4:1. Simplisia direndam dengan etanol $70 \%$ dan diaduk dengan maserator selama 3 jam dan didiamkan 24 jam. Filtrat disaring dan ampas selanjutnya diremaserasi sebanyak 2 kali. Filtrat hasil maserasi dijadikan satu kemudian etanol dihilangkan dengan rotary evaporator dan dipekatkan dalam waterbath (Vongsak et al., 2013)

\section{Formulasi Ekstrak Daun Kelor}

Ekstrak daun kelor diformulasikan dalam bentuk sediaan gel yang formulanya mengacu pada penelitian sebelumnya seperti disajikan pada Tabel 1 (Lena dan Sugihartini, 2015). Pada masing-masing formula tersebut konsentrasi ekstrak bervariasi 3\%, 6\% dan $9 \%$. Pembuatan gel diawali dengan mengembangkan gelling agent yaitu Karbopol 940 dalam $10 \mathrm{ml}$ air pada suhu $70^{\circ} \mathrm{C}$ dan kemudian ditambahkan ekstrak sehingga menjadi campuran 1. Metil paraben dilarutkan dalam sedikit air kemudian ditambahkan campuran gliserin, trietanolamin dan propilenglikol yang kemudian disebut campuran 2. Kedua campuran dijadikan satu, setelah itu diaduk dan ditambahkan air hingga 20 gram kemudian diaduk homogen 
Tabel 2. Hasil uji sifat fisik gel ekstrak daun kelor

\begin{tabular}{llll}
\hline Parameter Uji Sifat Fisik & FI & FII & FIII \\
\hline $\mathrm{pH}$ & $6,23 \pm 0,15$ & $5,9 \pm 0,1$ & $5,27 \pm 0,12$ \\
Daya sebar $\left(\mathrm{cm}^{2}\right)$ & $25,22 \pm 1,03$ & $32,87 \pm 3,12$ & $28,34 \pm 3,77$ \\
Daya Lekat (detik) & $6,43 \pm 0,70$ & $4,9 \pm 0,89$ & $5,6 \pm 0,7$ \\
Viskositas (poise) & $2,29 \pm 0,43$ & $1,62 \pm 0,18$ & $1,85 \pm 0,19$ \\
\hline
\end{tabular}

\section{Evaluasi Sifat Fisik Gel Ekstrak Daun Kelor}

Viskositas gel ditentukan dengan viskosimeter Brookfield $D V 2 T$. $\mathrm{pH}$ gel ditentukan dengan menggunakan $\mathrm{pH}$ meter.

Uji daya sebar dilakukan dengan meletakkan 0,5 gram gel pada kaca bulat, kaca lainnya diletakan di atasnya dan dibiarkan selama 1 menit. Setelah itu, ditambahkan 150 gram beban, didiamkan 1 menit dan diukur diameter konstan. Daya sebar dinyatakan dengan luas penyebaran (Astuti et al., 2010).

Uji daya lekat dilakukan dengan meletakkan 0,25 gram gel diantara 2 gelas objek pada alat uji daya lekat, kemudian ditekan beban $1 \mathrm{~kg}$ selama 5 menit. Beban diangkat dan beban 80 gram pada alat dilepaskan. Waktu yang dibutuhkan sehingga kedua objek gelas saling terlepas dicatat waktu pelepasan gel (Miranti, 2009).

\section{Evaluasi Daya Iritasi Ekstrak Gel Daun Kelor}

Evaluasi daya iritasi sediaan mengacu metode dari BPOM (2004) dengan menggunakan 3 ekor kelinci yang rata-rata berumur 3-6 bulan. Uji iritasi diawali dengan pencukuran rambut kelinci pada bagian punggungnya sampai bersih kemudian dioleskan perontok rambut (Veet) untuk membantu menghilangkan bulu halus. Punggung kelinci dibagi menjadi 5 area dengan luas yang sama. Masing-masing area diolesi sampel iritan (sediaan gel FI, FII, FIII, basis) sebanyak 0,5 gram dan dibiarkan selama 1 jam. Satu area tidak diberikan perlakuan sebagai kontrol. Setelah 1 jam, lalu diamati adanya efek tingkat eritema (reaksi kemerahan maupun parutan) dan tingkat udema (bengkak) yang timbul, kemudian hasil pengamatan tersebut diberikan 0-4, sesuai dengan tingkat keparahannya. Pengamatan dilakukan kembali setelah 24, 48 dan 72 jam.

\section{Uji Antiinflamasi}

Pada uji antiinflamasi digunakan hewan uji sebanyak 42 ekor mencit galur BALB/c. Hewan uji tersebut dibagi menjadi 7 kelompok percobaan yang meliputi kelompok yang tidak mendapatkan perlakuan apapun (kontrol sehat) dan kelompok yang mendapat induksi inflamasi dilanjutkan perlakuan dengan pemberian gel 3\%,6\%,
$9 \%$, basis, obat antiinflamasi di pasaran (kontrol positif) dan tidak mendapatkan perlakuan sediaan (kontrol negatif). Prosedur induksi inflamasi adalah pertamatama punggung mencit dicukur rambutnya sampai bersih. Setelah 24 jam punggung mencit ditetesi dengan $0,1 \mathrm{ml}$ croton oil konsentrasi $4 \%$ pada luas area $2 \times 2 \mathrm{~cm}$. Pengolesan sediaan sebesar $100 \mathrm{mg}$ dilakukan selama 30 menit setelah penetesan croton oil. Hari berikutnya juga diberi perlakuan yang sama. Perlakuan tersebut dilakukan selama 3 hari. Setelah itu mencit dikorbankan dan diambil kulitnya bagian punggungnya untuk dibuat preparat pengecatan HE. Berdasarkan hasil pengecatan dapat diukur tebal epidermis (Sugihartini, 2013). Prosedur penelitian telah mendapatkan surat keterangan dari Komite Etik Penelitian Universitas Ahmad Dahlan Nomor 011604072 .

\section{Analisis Data}

Data hasil uji sifat fisik dan antiinflamasi dianalisis one way ANOVA dilanjutkan dengan paired t-test dengan taraf kepercayaan $95 \%$ untuk mengetahui perbedaan antar kelompok perlakuan dengan menggunakan software SPSS.

\section{HASIL DAN PEMBAHASAN}

Hasil uji sifat fisik gel (viskositas, $\mathrm{pH}$, daya sebar, daya lekat) disajikan pada Tabel 2. Pengujian viskositas bertujuan untuk mengetahui mudah tidaknya suatu sediaan untuk diaplikasikan yang ditunjukkan dari kemampuan dalam mengalir. Selain itu viskositas dapat digunakan sebagai parameter kestabilan dan dapat mempengaruhi daya lekat serta daya sebar suatu sediaan. Hasil uji menunjukkan bahwa terjadi penurunan viskositas dengan penambahan ekstrak daun kelor. Hal ini kemungkinan disebabkan penambahan konsentrasi ekstrak menyebabkan pula peningkatan jumlah pelarut yang ada di dalamnya sehingga gel menjadi lebih encer. Hal ini terlihat dari data bahwa terdapat perbedaan signifikan antara FI dengan FII. Meskipun demikian ternyata antara F I dengan FIII serta FII dengan FIII menunjukkan tidak adanya perbedaan yang signifikan. Penurunan viskositas pada gel juga berkesesuaian dengan penurunan $\mathrm{pH}$. 
Tabel 3. Hasil uji iritasi gel ekstrak daun kelor dengan berbagai perlakuan

\begin{tabular}{lll}
\hline Kelompok Uji & Indeks Iritasi & Keterangan \\
\hline Kontrol Sehat & 0 & Sangat ringan (negligible) \\
Basis & 0 & Sangat ringan (negligible) \\
FI & 0 & Sangat ringan (negligible) \\
FII & 0 & Sangat ringan (negligible) \\
FIII & 0 & Sangat ringan (negligible) \\
\hline
\end{tabular}

Gel dalam penelitian ini merupakan tipe Hidrogel dengan gelling agent Karbopol di mana perubahan $\mathrm{pH}$ akan mempengaruhi sifat fisik gel. Berdasarkan Tabel 2 diketahui bahwa antara ketiga formula ekstrak maka formula III memiliki $\mathrm{pH}$ yang lebih rendah. Hasil statistik menunjukkan bahwa perbedaan yang signifikan terdapat antara FI dengan FIII. Hal ini kemungkinan disebabkan kandungan Vitamin $\mathrm{C}$ dalam ekstrak daun kelor dimana Vitamin $\mathrm{C}$ ini bersifat asam sehingga mampu menurunkan nilai $\mathrm{pH}$ (Hardiyanthi, 2015). Konsentrasi trietanolamin yang lebih rendah pada gel dengan konsentrasi ekstrak yang tinggi juga menurunkan $\mathrm{pH}$ gel. Secara keseluruhan gel memiliki $\mathrm{pH}$ pada rentang $\mathrm{pH}$ kulit normal yaitu antara 4,5 - 6,5 (Djajadisastra et al., 2009). Kesesuaian pH kulit dengan $\mathrm{pH}$ sediaan topikal mempengaruhi penerimaan kulit terhadap sediaan. Sediaan topikal yang ideal adalah tidak mengiritasi kulit. Kemungkinan iritasi kulit akan sangat besar apabila sediaan terlalu asam atau terlalu basa (Susilowati dan Wahyuningsih, 2014).

Pengujian daya lekat bertujuan untuk melihat kemampuan salep melekat di kulit yang ditunjukkan dengan lamanya waktu melekat (Astuti et al., 2010). Syarat untuk daya lekat pada sediaan topikal adalah tidak kurang dari 4 detik (Ulaen et al., 2012). Peningkatan konsentrasi ekstrak ternyata menurunkan daya lekat gel. Hal ini berkaitan dengan data viskositas yang menunjukkan adanya penurunan viskositas dengan adanya penambahan konsentrasi ekstrak. Semakin rendah viskositas maka akan menurunkan daya lekat. Data ini berkesesuaian dengan hasil penelitian Haque dkk (2015) yang menunjukkan bahwa peningkatan konsentrasi minyak atsiri dalam krim tipe M/A akan menurunkan daya lekat krim. Hasil statistik menunjukan bahwa antara formula gel dengan variasi konsentrasi ekstrak tersebut memiliki perbedaan yang tidak signifikan.

Pengujian daya sebar gel ekstrak daun kelor bertujuan untuk melihat kemampuan sediaan menyebar pada kulit. Gel yang memiliki daya sebar yang baik akan memberikan penyebaran bahan obat yang baik sehingga pengobatan diharapkan akan lebih efektif (Naibaho et al., 2013). Syarat daya sebar sediaan topikal sekitar 5-7 cm (Ulaen et al., 2012). Daya sebar pada penelitian ini diperoleh hasil sesuai dengan syarat daya sebar yang disyaratkan. Hasil uji menunjukkan bawa peningkatan konsentrasi ekstrak menyebabkan kecenderungan peningkatan daya sebar gel. Hal tersebut juga sesuai dengan hasil data viskositas. Peningkatan konsentrasi ekstrak menyebabkan penurunan viskositas sehingga daya sebar gel akan meningkat. Data ini berkesesuaian dengan hasil penelitian Haque dkk. (2015), Sari dkk (2015), Mukhlishah dkk (2016), Pranawati dkk (2016) dan Pratimasari dkk (2016) yang menunjukkan peningkatan daya sebar sediaan dengan adanya peningkatan kosentrasi minyak atsiri dalam salep basis krim tipe $\mathrm{A} / \mathrm{M}$, krim tipe $\mathrm{M} / \mathrm{A}$, emulgel, hidrokarbon dan larut air. Hasil statistik menunjukan ada perbedaan yang signifikan antara FI-FII dan juga antara FI-FIII.

Pengamatan selanjutnya dilakukan terhadap uji iritasi dengan hasil pengamatan seperti disajikan pada Tabel 3. Hasil uji menunjukkan bahwa pemberian gel ekstrak daun kelor tidak menyebabkan iritasi. Gambar hasil uji iritasi disajikan pada Gambar 1.

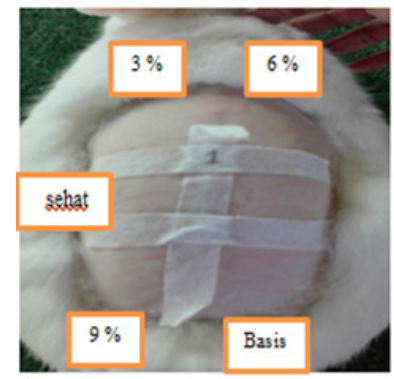

Gambar 1. Hasil uji iritasi pada punggung kelinci

Selain sifat fisik dan daya iritasi maka gel juga dievaluasi daya antiinflamasinya dengan parameter tebal epidermis seperti disajikan pada Tabel 4. Berdasarkan literatur diketahui bahwa inflamasi kronis dapat menyebabkan infiltrasi makrofag, sel dendritis, T Sel serta penebalan epidermis (Silver et al., 2012). Zat aktif dalam sediaan topikal tersebut diharapkan akan dapat berdifusi keluar dari sediaan untuk dapat memberikan efek pada kulit. Proses difusi dan penetrasi dari zat aktif tersebut dipengaruhi oleh formula sediaan tersebut (Santos et al., 
Tabel 4. Tebal epidermis kulit punggung mencit dengan berbagai perlakuan $(n=6)$

\begin{tabular}{ll}
\hline Perlakuan & $\begin{array}{l}\text { Ketebalan epidermis }(\boldsymbol{\mu m}) \\
\text { (Rata-rata } \pm \text { SD) }\end{array}$ \\
\hline Kontrol Sehat $^{*}$ & $36,65 \pm 6,9$ \\
Kontrol Sakit & $149,65 \pm 20,08$ \\
Kontrol Positif & $81,11 \pm 10,16$ \\
Kontrol Basis $^{*}$ & $125,64 \pm 16,14$ \\
F I $^{* \#}$ & $93,23 \pm 6,7$ \\
F II $^{* \#}$ & $103,27 \pm 11,88$ \\
F III $^{* \#}$ & $90,31 \pm 26,6$ \\
\hline
\end{tabular}

Keterangan : * Berbeda signifikan dengan kontrol sakit \# Berbeda signifikan dengan kontrol sehat

2018; Yakota dan Kyotani, 2018). Gambaran mikroskopi tebal epidermis disajikan pada Gambar 2. Hasil uji statistik menunjukkan bahwa terdapat perbedaan yang signifikan antara Kontrol Sehat dengan Kontrol Sakit. Ini menunjukkan bahwa induksi dengan Croton oil mampu menyebabkan inflamasi. Mekanisme Croton oil sebagai induktor inflamasi adalah dengan meningkatkan NF- $\mathrm{KB}$ yang dapat menginduksi papiloma pada kulit tikus dan mampu menimbulkan bengkak pada kulit sehingga terjadi hyperplasia dan infiltrasi dari leukosit (Subramanian dan Vellaichany, 2014; Boligou et al., 2017; Fang et al., 2018). Crotton oil mengandung senyawa phorbol ester sebagai bagian utama 12-o-tetra-cauvilphorbol-13acetate (TPA) yang dapat memicu inflamasi (Santos et al., 2018). Perbedaan signifikan juga ditunjukkan antara Kontrol Sakit dan Kontrol Positif. Hal ini berarti sediaan antiinflamasi yang ada di pasaran dengan bahan aktif natrium diklofenak dapat memberikan efek antiinflamasi yang baik karena dapat menurunkan ketebalan epidermis secara signifikan. Beberapa penelitian sebelumnya juga telah menggunakan natrium diklofenak sebagai kontrol positif pada uji antiinflamasi secara topikal (Srirod dan Tewtrakul, 2019; Dev et al., 2019; Carvalho et al., 2019). Penelitian Carvalho dkk. (2019) menunjukkan bahwa t max Natrium diklofenak yang diberikan secara topikal adalah 4 jam sesudah diaplikasikan di kulit. Basis gel yang digunakan dapat menurunkan ketebalan epidermis namun tidak berbeda signifikan dengan kelompok Kontrol Sakit. Ini berarti basis yang digunakan tidak memberikan aktivitas antiinflamasi.

Pemberian gel ekstrak daun kelor dapat menurunkan ketebalan epidermis secara signifikan apabila dibandingkan dengan Kontrol Sakit. Hal ini menunjukkan aktivitas ekstrak daun kelor sebagai antiinflamasi. Ekstrak daun kelor mengandung senyawa flavonoid

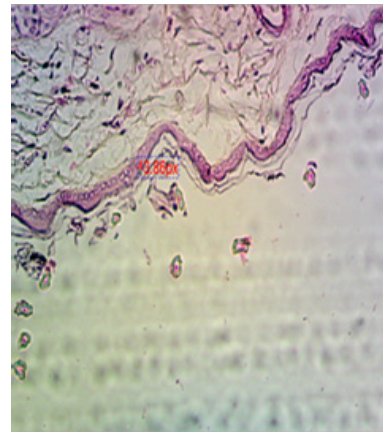

(a)

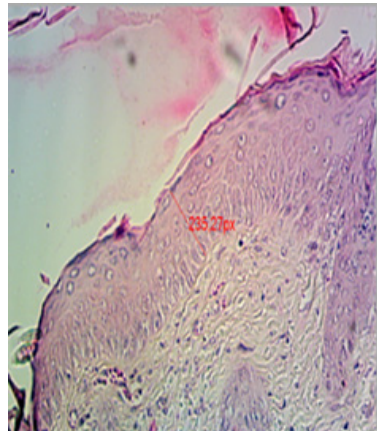

(b)

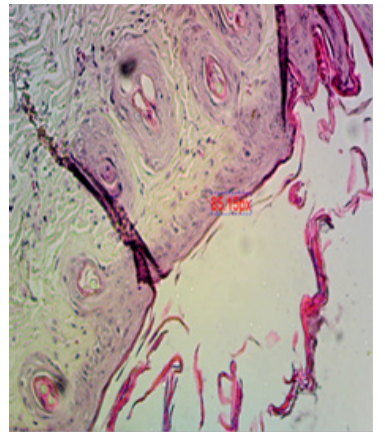

(c)

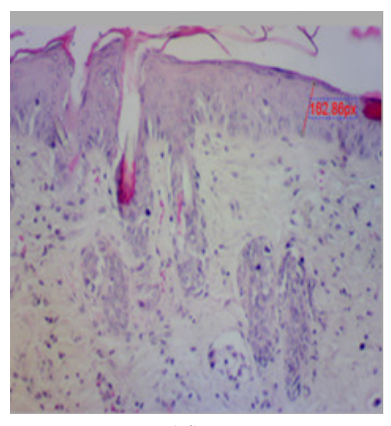

(d)

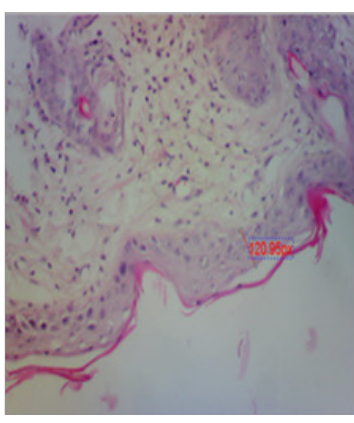

(e)

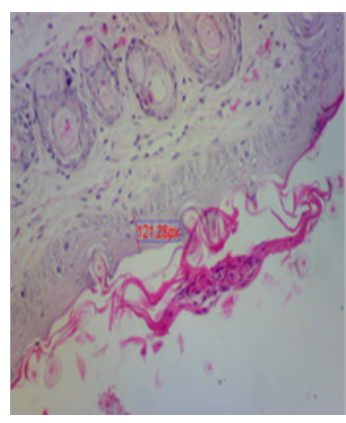

(f)

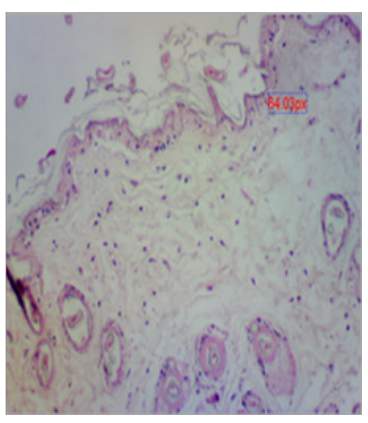

(g)

Gambar 2. Mikrofotografi tebal epidermis kulit kontrol sehat (a), kontrol negatif (b), kontrol positif (c), kontrol basis (d), gel konsentrasi ekstrak 3\% (e), gel konsentrasi ekstrak $6 \%$ (f), gel konsentrasi ekstrak $9 \%$ (g) dengan perbesaran $400 x$ 
yang mempunyai kemampuan antioksidan sehingga dapat menghambat aktivitas enzim siklooksigenase dan sintesis prostaglandin yang merupakan mediator inflamasi (Singh et al., 2012). Selain itu flavonoid memiliki mekanisme penghambatan akumulasi leukosit, penghambatan degranulasi netrofil, penghambatan pelepasan histamin. Penghambatan akumulasi leukosit selama proses inflamasi akan menyebabkan penurunan respon tubuh terhadap inflamasi, penghambatan ini terjadi karena adanya penghambatan pada COX sehingga tromboksan akan dihambat dimana tromboksan ini akan menyebabkan modulasi leukosit. Penghambatan degranulasi netrofil akan mengurangi pelepasan asam arakhidonat oleh netrofil. Penghambatan pelepasan histamin terjadi karena flavonoid dapat menghambat pelepasan histamin dari sel mast (Riansyah et al., 2015). Aktivitas antiinflamasi gel dengan konsentrasi ekstrak daun kelor 3\% dan 9\% ternyata tidak berbeda signifikan dengan Kontrol Positif. Ini berarti aktivitas gel ekstrak daun kelor sama dengan aktivitas natrium diklofenak. Namun demikian, ketebalan epidermis pada kelompok yang diberikan gel ekstrak daun kelor masih berbeda signifikan dengan kelompok Kontrol Sehat. Ini berarti pemberian gel ekstrak daun kelor masih belum mampu mengembalikan kondisi kulit yang mengalami inflamasi seperti kondisi sebelumnya. Hal ini kemungkinan disebabkan lama pemberian gel ekstrak daun kelor baru selama 3 hari sehingga aktivitas ekstrak daun kelor belum maksimal. Perbedaan konsentrasi ekstrak daun kelor ternyata memberikan aktivitas antiinflamasi yang berbeda tidak signifikan. Ini berarti aktivitas antiinflamasi gel dengan konsentrasi 3\% sama dengan konsentrasi $6 \%$ dan 9\%.

\section{KESIMPULAN}

1. Gel ekstrak daun kelor tidak mengiritasi dan menurunkan tebal epidermis dibandingkan dengan kontrol sakit dan kontrol basis, yang mengindikasikan aktivitas antiinflamasi gel ekstrak daun kelor

2. Konsentrasi optimum ekstrak daun kelor pada gel dalam penelitian ini yaitu konsentrasi 3\% ditinjau dari viskositas, daya lekat, daya sebar dan $\mathrm{pH}$ sediaan serta penurunan tebal epidermis.

\section{UCAPAN TERIMA KASIH}

Terimakasih kepada Lembaga Penelitian dan Pengembangan Universitas Ahmad Dahlan yang telah memberikan dana penelitian melalui skema Penelitian Hibah Bersaing tahun 2016.

\section{DAFTAR ACUAN}

Astuti, I.Y., Hartanti, D., \& Aminiati, A. (2010). Peningkatan aktivitas antijamur Candidia albicans salep minyak atsiri daun sirih (Piper bettle LINN.) melalui pembentukan kompleks inklusi dengan $\beta$-siklodekstrin. Majalah Obat Tradisional,15, 94-99.

Badan Pengawas Obat dan Makanan. (2014). Badan Pengawas Obat dan Makanan RI Pedoman Uji Toksisitas Non-Klinik Secara In-Vivo. Jakarta:Badan Pengawas Obat dan Makanan RI

Boligou, A.A., Moreira, L.R., Piana, M., Campos, M.M.A., Oleivera, S.M. (2017). Topical anti edematogenic and anti-inflammatory effect of Scutia buxifolia Reissek gel and stability study. Journal of Photochemistry and Photobiology, B, 167, 29-35

Carvalho, R.L.P., Leonardo, P.S.L.M., Mendes, G.D., Lima, F.P.S., Lina, M.O., Marcos, R.L., Martins, R.A.B.L. (2019). Pharmacokinetic and Pharmacodynamics of Sodium diclofenac (Topical and IM) associated with laser photobiomodulation on skeletal muscle strain in rats. International Journal of Photoenergy, 1, 12

Corwin, E.J. (2008). Handbook of Pathophysiology. $3^{\text {th }}$ edition, Philadelphia:Lippincort Williams \& Wilkins. Dev, S.K., Choudhury, P.K., Srivastana, R., Sharma, M. (2019). Antimicrobial, anti-inflammatory and wound healing activity of polyherbal formulation. Biomedicine \& Pharmacotherapy, 111, 555-567

Djajadisastra, J., Mun'im, A., Desi, N.P. (2009). Formulasi gel topikal dari ekstrak Nerii folium dalam sediaan antijerawat. Jurnal Farmasi Indonesia, 4(4), 210-216

Fang, X.Y., Zhen, H., Po, I.S., Nan, C.J., Ren, S.Z., Ping, L.X., Xin, L.Z. (2018). Comparison of the antiinflammatory effects of Sinapis alba and Brassica juncea in mouse models of inflammation. Phytomedicine, 50, 196-204

Goodman, G. (2003). Dasar Farmakologi Terapi. Edisi 10, Volume 2, Jakarta:Penebit Buku Kedokteran EGC Gupta, G.D \& Gand, R.S. (2006). Antiinflammatory activity of Tenoxicam gel on carrageenan-induced paw oedem in rats. Indian Journal of Pharmaceutical Science, 356-359

Hardayanthi, F. (2015). Pemanfaatan aktivitas antioksidan ekstrak daun Kelor (Moringa oleifera) dalam sediaan hand and body cream. Skripsi. Jakarta : FSTUIN Syari Hidayatullah Jakarta. 
Haque, A.F., Sugihartini, N., Yuwono, T. (2015). Evaluasi uji iritasi dan uji sifat fisik pada sediaan krim M/A minyak atsiri bunga cengkeh (Syzigium aromaticum) dengan berbagai variasi konsentrasi. Pharmacy, 12(2), 131

Lena, M., Sugihartini, N. (2015). Formulasi gel ekstrak etanol kulit buah manggis (Garcinia mangostana L.) dengan variasi gelling agent sebagai sediaan luka bakar. Pharmaciana, 5(1), 43-52

Lima, G.R.M., Montenegro, C.A., Almeida, C.L.F., Athayde-Filho, P. F., Barbosa-Filho, J. M., \& Batista, L.M. (2011). Database survey of anti-inflammatory plants in South America: a review. International Journal of Molecular Science, 12(4), 2692-2749.

Lutfiana. (2013). Uji antiinflamasi ekstrak daun kelor (Moringa oleifera Lam.) dengan metode stabilisasi membran sel darah merah secara in vitro. Jurnal Ilmiah, Jakarta : Program Studi Farmasi Fakultas Kedokteran dan Ilmu Kesehatan

Mahajan, S.G., Mali, R.G., \& Mehta, A.A. (2007)a . Effect of Moringa oleifera Lam. Seed extract on toluene diisocyanate-induced immune-mediated inflammatory respons in rats. Journal of Immunotoxicology, 4, 85-96

Mahajan, S.G., Mali, R.G., \& Mehta, A.A. (2007) ${ }^{b}$. Protective effect of ethanolic extract of seeds of Moringa oleifera Lam. against inflammation associated with development of arthritis in rats. Journal of Immunotoxicology, 4, 39-47

Miranti, L. (2009). Pengaruh konsentrasi minyak atsiri Kencur (Kaempferia galanga) dengan basis salep larut air terhadap sifat fisik salep dan daya hambat bakteri Staphylococus aureus secara In Vitro. Skripsi, Fakultas Farmasi Universitas Muhamadiyah, Surakarta.

Mukhlishah, N.R.I., Sugihartini, N., Yuwono, T. (2016). Daya iritasi dan sifat fisik sediaan salep minyak atsiri bunga cengkeh (Syziqium aromaticum) pada basis hidrokarbon. Majalah Farmaseutik, 12(1), 372-376

Naibaho, D.H., Yamkan, V,Y., Weni, Wiyono. (2013). Pengaruh basis salep terhadap formulasi sediaan salep ekstrak daun Kemangi (Ocinum sanchum L.) pada kulit punggung kelinci yang dibuat infeksi Staphylococcus aureus. Jurnal Ilmiah Farmasi - UNSRAT, 2(02)

Pranawati, E., Sugihartini, N., Yuwono, T. (2016). Sifat fisik dan daya iritasi krim tipe A/M minyak atsiri bunga cengkeh (Syziqium aromaticum) dengan berbagai variasi konsentrasi. Jurnal Ilmiah Farmasi, 12(1), 1-9
Pratimasari, D., Sugihartini, N., Yuwono, T. (2015). Evaluasi sifat fisik dan uji iritasi sediaan salep minyak atsiri bunga Cengkeh (Syziqium aromaticum) dalam basis larut air. Jurnal Ilmiah Farmasi, 11(1), 9-15

Riansyah, Y., Lanny, M., Ratu, C. (2015). Uji aktivitas antiinflamasi ekstrak etanol daun ubi Jalar Ungu (Ipomoea batatas (L.) Lamk) terhadap tikus whistar jantan. Prosiding Penelitian SPeSIA Unisba 2015 (pp630-636). ISNN 2460-6472. Bandung

Santos, J.B.X., Silva, J.F., Passos, J.G.R., Gomes, J.A.S., Fernandes, J.M., Garcia, V.B., Junior, R.F.A., Zucolotto, S.M., Junior, A.A.S., Pedrosa, M.F.F. (2018). Development of an effective and safe topical antiinflammatory gel containing Jatropa gossypiifolia leaf extract : results from a pre-clinical trial in mice. Journal of Ethnopharmacology, 227, 268-278

Sari, D.K., Sugihartini, N., Yuwono, T. (2015). Evaluasi uji iritasi dan uji sifat fisik sediaan emulgel minyak atsiri bunga Cengkeh (Syziqium aromaticum). Pharmaciana, $5(2), 115-120$

Silver, R., Helnis, A., Fu, W., Wang, H., Diaconu, D., Loyd, C.M., Rollins, A.M., Ward, N.L. (2012). Using optical coherence tomography for the longitudinal noninvasive evaluation of epidermal thickness in a murine model of chronic skin inflammation. Skin Research and Technology, 18, 225-231

Singh, G.P., Rakesh, G., Sudeep, B., Kumar, S. (2012). Anti-inflammatory evaluation of leaf extract of Moringa oleifera. Journal of Pharmaceutical and Scientific Innovation, 1(1), 22-24

Souto, A.L., Tavares, J.F., Da Silva, M.S., Diniz, M.F.F.M., De Athayde-Filho, P.F., \& Barbosa Filho, J.M. (2011). Anti-inflammatory activity of alkaloids: an update from 2000 to 2010. Molecules, 16(10), 85158534

Srirod, S., Tewtrakul, S. (2019). Anti-inflammatory and wound healing effects of cream containing Curcuma mangga extract. Journal of Ethnopharmacology, S03788741(18), 33813-3

Subramanian, V., Vellaichamy, E. (2014). Atrial natriuretik peptide (ANP) inhibiting DMBA/croton Oil induced skin tumor growth by modulating NF- $\kappa$ B, MMPs and infiltrating Mast Cells in Swis Albino mice. European Journal of Pharmaceutical Science, 740, 388397 
Sugihartini, N. (2013) Optimasi komposisi enhancer dan emulgator pada formulasi krim fraksi etil asestat ekstrak teh hijau (Camellia sinensis, L) sebagai sediaan topikal anti inflamasi. Disertasi, Program Pascasarjana Universitas Gadjah Mada, Yogyakarta

Susilowati, E.P., Wahyuningsih, S.S. (2014). Optimasi sediaan salep yang mengandung eugenol dari isolasi minyak Cengkeh (Eugenia caryophylatta Thunb.). Indonesian Journal On Medical Science, 1, 2.

Ulaen, S.P.J., Banne, Y., Suatan, R.A. (2012). Pembuatan salep anti jerawat dari ekstrak rimpang Temulawak (Curcuma xanthorrhiza Roxb.). Jurnal Ilmiah Farmasi, 3(2), 45-49

Vongsak, B., Sithisarn, P., Mangmool, S., Thongpraditchote, S., Wongkrajang, Y., Gritsanapan, W. (2013). Maximizing total phenolics, total flavonoids contents and antioxidant activity of Moringa oleifera Leaf extract by the appropriate extraction method. Industrial Crops and Products, 44, 566-571
Yakota, J., Kyotani, S. (2018). Influence of nanoparticle size on the skin penetration, skin retention and antiinflammatory activity of non-steroidal anti-inflammatory drugs. Journal of The Chinese Medical Association, 81, 511-519

Zhang, Y., Xia, Q., Li, Y., He, Z., Li, Z., Guo, T., Wu, Z., Feng, N. (2019). CD44 assists the topical antipsoriatic efficacy of curcumin-loaded hyaluronanmodified ethosomes: a new strategy for clustering drug in inflammatory skin. Theranostic, 9(1), 48-64 